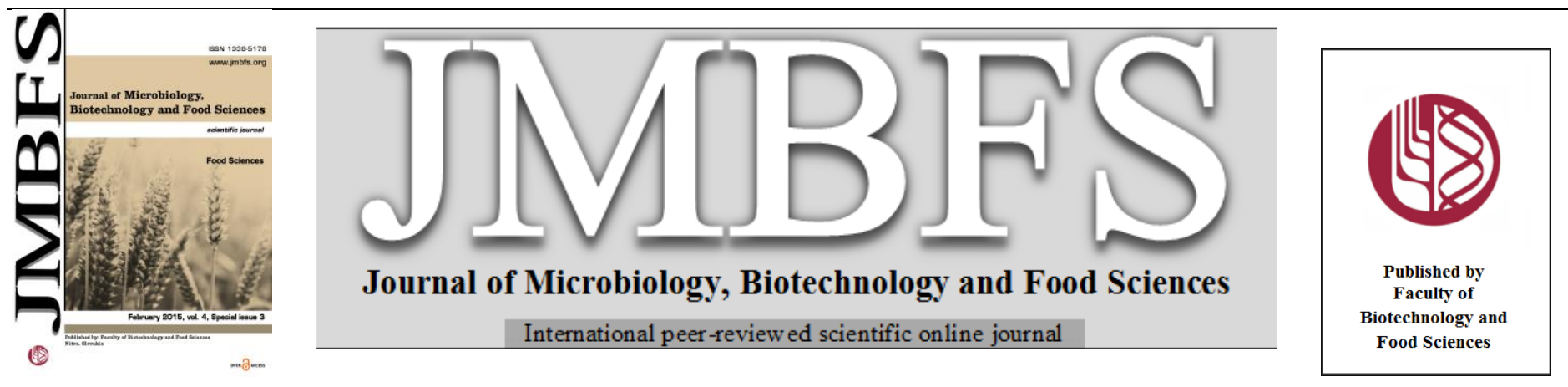

\title{
QUALITY EVALUATION OF UNIFLORAL AND MULTIFLORAL HONEYS FROM SLOVAKIA AND OTHER COUNTRIES
}

\author{
Vladimíra Ǩ̌azovická*l, Bianka Mederiová2, Peter Haščík ${ }^{1}$, Miroslava Trnková2, Miroslava Kačániová3
}

Address(es): Ing. Vladimíra Kňazovická, PhD.

${ }^{1}$ Slovak University of Agriculture in Nitra, Faculty of Biotechnology and Food Sciences, Department of Animal Products Evaluation and Processing, Tr. A. Hlinku 2, 94976 Nitra, The Slovak republic, phone number: +421 376414428.

${ }^{2}$ Graduated in Food Technology (in 2012) at Faculty of Biotechnology and Food Sciences, Slovak University of Agriculture in Nitra.

${ }^{3}$ Slovak University of Agriculture in Nitra, Faculty of Biotechnology and Food Sciences, Department of Microbiology, Tr. A. Hlinku 2, 94976 Nitra, The Slovak republic.

*Corresponding author:vladimira.knazovicka@uniag.sk

doi: 10.15414/jmbfs.2015.4.special3.82-86

ARTICLE INFO

Received 5. 11. 2014

Revised 10. 11. 2014

Accepted 11. 11. 2014

Published 2. 2. 2015

Regular article

open 2 access

\begin{abstract}
The aim of the study was to evaluate the blossom honey samples divided into the three groups: acacia (Robinia psedoacacia) honeys $(\mathrm{n}=14)$, other unifloral honeys (clover Trifolium pratense, lime Tilia cordata, rape Brassica napus, buckwheat Fagopyrum esculentum, chestnut Castanea sativa; $\mathrm{n}=8)$ and multifloral honeys $(\mathrm{n}=16)$. We tested the physico-chemical and microbiological quality of honeys. Followed physico-chemical parameters were tested: water, water content, hydroxymethylfurfural (HMF), $\mathrm{pH}, \mathrm{free}$ acidity and diastase. From microbiological parameters, we found total plate count (TPC), TPC of anaerobic microorganisms, counts of coliform bacteria, sporulating bacteria and microscopic fungi in the honey samples using dilution plating method. Water content ranged from 13.60 to

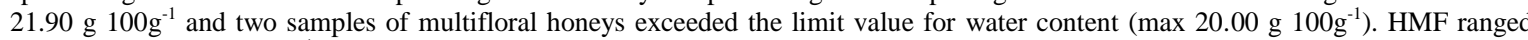
from 0.77 to $10.93 \mathrm{mg} \mathrm{kg}^{-1}$ that is typical for fresh and heat-untreated honeys. Average values of $\mathrm{pH}$ were $5.02 \pm 0.25$ for acacia honey, $4.98 \pm 0.31$ for other unifloral honeys and $4.66 \pm 0.45$ for multifloral honeys. One sample of multifloral honeys exceeded the limit value for free acidity (max $50 \mathrm{meq} \mathrm{kg}^{-1}$ ). Higher TPC (above $2.00 \log \mathrm{CFU} \mathrm{g} \mathrm{g}^{-1}$ ) was detected in 2 out of 14 acacia honeys $(14.29 \%$ ), in 2 out of 8 other unifloral honeys $(25.00 \%)$ and in 5 out of 16 multifloral honeys $(31.25 \%)$. Microscopic fungi were not found in 3 acacia honeys $(21.43 \%), 2$ other unifloral honeys $(25.00 \%)$ and 2 multifloral honeys (12.50\%). Overall, the obtained results showed good quality of evaluated honeys.
\end{abstract}

Keywords: Blossom honey, physico-chemical parameters, microorganisms

\section{INTRODUCTION}

Blossom honey and honeydew honey are two main honey types in term of its origin. Blossom honey comes from nectar of plants. In practical terms there are unifloral and multifloral types of blossom honey. Beekeepers only obtain unifloral honey from profuse crops, for example Brassica napus, Robinia pseudoacacia or Rubus ideaus (Veselý et al., 2003). In such a case, the honey is labelled according to the dominant plant species (Kamler et al., 1999). Multifloral honey is accrued from several plant sources; bees deposit nectar and pollen of several plants and transfer from cell to cell depending on necessity (Titěra, 2006). The use of botanical appellation of honey together with geographical origin is becoming a good option to protect and promote this traditional food in different countries (Juan-Borrás et al., 2014). It is expected that honey properties from different botanical sources and location are different (Mărghitas et al., 2009). In Slovakia typical unifloral honeys are from lime (Tilia cordata), acacia (Robinia pseudoacacia), sunflower (Helianthus annus), rape (Brassica napus) or clover (Trifolium pratense).

Honey consists of sugars, water, organic acids, enzymes and other substances as proteins, aminoacids, vitamins, minerals, acetylcholine, flavonoids and various organic compounds (pollen grains, wax particles) (Kukurová et al., 2009). In general blossom honeys contain higher amount of proteins, smaller amount of minerals and oligosaccharides compared to honeydew honeys. Main sugars in blossom honeys are the monosaccharides fructose and glucose and the principal oligosaccharides are the disaccharides sucrose, maltose, trehalose and turanose as well as some nutritionally relevant ones such as panose, 1-kestose, 6-kestose and palatinose (Bogdanov et al., 2008). Characteristic compound of honey, produced from the acid-catalyzed degradation of sugars (mainly fructose), is HMF (5hydroxymethylfurfural) (Zielińska et al., 2014), which appears during ageing or heating of honey (Amir et al., 2010). The water content is a good criterion to establish the quality of honey; a higher content can produce honey fermentation during storage (Mărghitas et al., 2009). Enzymes are the most important and also the most interesting honey components; they are accountable for the conversion of nectar to honey, and serve as a sensitive indicator of the honey treatment (Vorlová and Čelechovská, 2002).

One of the honey valuable properties is its antimicrobial activity against pathogenic vegetative bacteria, microscopic filamentous fungi and protozoa (Kisala and Dżugan, 2009). The natural acidity of this product, the low protein content and the high viscosity, that limit the atmospheric oxygen penetration, are particularly stressing for several microorganisms (Sinacori et al., 2014) However, honey is not sterile material completely. The predominant microorganisms found in honey are derived from the nectar and the honey bee (Chaven, 2014). The biodiversity and quantity of microorganisms in honey are variable and unique to the honey sample analysed. They are dependent on honey quality (properties of honey), which is determined by a variety of factors during honey production and treatment. According to Snowdon and Cliver (1996) microbial survival may be influenced mainly by the type of honey and its moisture content. Sinacori et al. (2014) analyzed some nectar (blossom) and honeydew honeys from Italia and they found 13 species of bacteria, 5 species of yeasts and 17 species of microscopic filamentous fungi; the species most frequently isolated were Bacillus amyloliquefaciens, Zygosaccharomyces mellis and Aspergillus niger for the three microbial groups, respectively. Sporulating bacteria, microscopic filamentous fungi and yeasts are typically found in honey, often at low numbers, while spores can persist indefinitely (Snowdon and Cliver, 1996). According to Różańska (2011) bacteria are not able to multiply in honey; their high number could indicate contamination during processing, handling or storage. Vegetative forms of pathogenic bacteria have never been found in honey (Snowdon and Cliver, 1996).

The aim of the study was to evaluate three groups of blossom honey samples: acacia honeys, other unifloral honeys and multifloral honeys. Samples were analyzed from physico-chemical and microbiological viewpoint. 


\section{MATERIAL AND METHODS}

\section{Honey samples}

We analysed 38 samples of blossom honeys. Honeys originated mainly in Slovakia $(n=35)$ and they were divided into three groups: acacia honeys $(n=14)$, other unifloral honeys $(\mathrm{n}=8)$ ) clover (Trifolium pratense, $\mathrm{n}=1$ ), lime (Tilia cordata, $\mathrm{n}=1$ ), rape (Brassica napus, $\mathrm{n}=3$ ), buckwheat (Fagopyrum esculentum $\mathrm{n}=1$ ), chestnut (Castanea sativa, $\mathrm{n}=2$ ) and multifloral honeys $(\mathrm{n}=16)$. The detailed characterization of evaluated samples is in the Table 1. Honeys were produced in 2009-2010. Before the physico-chemical parameters were determined, the primary treatment of samples in accordance with the IHC (2009) was performed, which emphasizes sample homogenization and the exclusion of air.

\section{Physico-chemical analyses}

The water content and water activity were measured simultaneously. The water content was detected using a portable refractometer HHR-2N (ATAGO ${ }^{\circledR}$, Japan) and water activity was detected using a Novasina LabMaster (Pfaffinon, Switzerland).

HMF content was measured by using the RQflex $10^{\circledR}$ and Hydroxymethylfurfural test (Merck, Germany) in undiluted honey samples.

The free acidity was measured by titration method according to the IHC (2009) And $\mathrm{pH}$ of honey solution intended for free acidity detection was measured using Whatman ${ }^{\circledR} \mathrm{pH}$ indicator papers with range of $\mathrm{pH}$ 3.8-5.5 (Whatman ${ }^{\circledR}, \mathrm{UK}$ ).

Diastase activity was detected according to Phadebas (Phadebas ${ }^{\circledR}$, Magle AB Sweden) in accordance with IHC (2009).

\section{Microbiological analyses}

The samples were analyzed by dilution plating method for the quantitative determination of total plate count (TPC), TPC of anaerobic microorganisms, counts of coliform bacteria, sporulating bacteria and microscopic fungi (yeast and microscopic filamentous fungi). The characteristics of method are shown in the Table 2 .

\begin{tabular}{llll}
$\mathbf{6}$ & acacia & Piestany, SR & 2009 \\
$\mathbf{7}$ & acacia & Vranov nad Toplou, SR & 2009 \\
$\mathbf{8}$ & acacia & Trnovec nad Vahom, SR & 2009 \\
$\mathbf{9}$ & acacia & Sala, SR & 2009 \\
$\mathbf{1 0}$ & acacia & Sebechleby, SR & 2009 \\
$\mathbf{1 1}$ & acacia & SR & 2009 \\
$\mathbf{1 2}$ & acacia & Rovne - Humenne, SR & 2009 \\
$\mathbf{1 3}$ & acacia & Kochanovce - Humenne, SR & 2009 \\
$\mathbf{1 4}$ & acacia & SR & 2009 \\
\hline $\mathbf{1 5}$ & buckwheat & Nedanicky, CR & 2009 \\
$\mathbf{1 6}$ & clover & Voderady, SR & 2009 \\
$\mathbf{1 7}$ & lime & Sebechleby, SR & 2009 \\
$\mathbf{1 8}$ & rape & Sebechleby, SR & 2009 \\
$\mathbf{1 9}$ & rape & Michalovce, SR & 2009 \\
$\mathbf{2 0}$ & rape & Rovne - Humenne, SR & 2009 \\
$\mathbf{2 1}$ & chestnut & Menges, Slovenia & 2010 \\
$\mathbf{2 2}$ & chestnut & V. Kladusa, Croatia & 2010 \\
\hline $\mathbf{2 3}$ & multifloral & Luckovce, SR & 2009 \\
$\mathbf{2 4}$ & multifloral & Detva, SR & 2009 \\
$\mathbf{2 5}$ & multifloral & Filakovo, SR & 2009 \\
$\mathbf{2 6}$ & multifloral & Kosice, SR & 2009 \\
$\mathbf{2 7}$ & multifloral & Kysak, SR & 2009 \\
$\mathbf{2 8}$ & multifloral & Stupava, SR & 2009 \\
$\mathbf{2 9}$ & multifloral & Bojnice, SR & 2009 \\
$\mathbf{3 0}$ & multifloral & Lefantovce, SR & 2009 \\
$\mathbf{3 1}$ & multifloral & Lefantovce, SR & 2009 \\
$\mathbf{3 2}$ & multifloral & Trnavoc nad Vahom, SR & 2009 \\
$\mathbf{3 3}$ & multifloral & Sala, SR & 2009 \\
$\mathbf{3 4}$ & multifloral & Velky Lapas, SR & 2009 \\
$\mathbf{3 5}$ & multifloral & Trebisov, SR & 2009 \\
$\mathbf{3 6}$ & multifloral & Male Krstenany, SR & 2010 \\
$\mathbf{3 7}$ & multifloral & SR & 2010 \\
$\mathbf{3 8}$ & multifloral & SR & 2010 \\
\hline Legend: clover (Trifolium & pratense), lime (Tilia cordata), rape $($ Brassica napus), buckwheat \\
Fagopyrum esculentum), chestnut (Castanea sativa), SR - The Slovak republic, CR - The & \\
Czech & republic & & \\
& & & \\
& & & \\
& &
\end{tabular}

Table 1 Characterisation of blossom samples

\begin{tabular}{llll}
\hline no. & Honey type & Geographical location & Production year \\
\hline $\mathbf{1}$ & acacia & Drazovce-Nitra, SR & 2009 \\
$\mathbf{2}$ & acacia & Hanusovce nad Toplou, SR & 2009 \\
$\mathbf{3}$ & acacia & Velky Meder, SR & 2009 \\
$\mathbf{4}$ & acacia & Krupina, SR & 2009 \\
$\mathbf{5}$ & acacia & Bzovik, SR & 2009
\end{tabular}

\section{Statistical analysis}

The measurement data were calculated to appropriate units. For each honey group, followed statistical parameters were found by MS Excel 2007: the number of values with measured (non-zero) values (n), average, standard deviation (SD), minimum (min), maximum $(\max )$ and coefficient of variation (coef. var.).

Table 2 Microbiological analysis of honey

\begin{tabular}{|c|c|c|c|c|c|}
\hline \multirow{2}{*}{ Microbial group } & \multirow{2}{*}{ Medium } & \multirow{2}{*}{ Inoculation } & \multicolumn{3}{|c|}{ Conditions of cultivation } \\
\hline & & & $\mathrm{O}_{2}$ Req. & Temp. & Time \\
\hline Coliform bacteria & VRBL & spreading & aerobic & $37^{\circ} \mathrm{C}$ & $24 \mathrm{~h}$ \\
\hline $\mathrm{TPC}$ & GTY & pouring & aerobic & $30^{\circ} \mathrm{C}$ & $48-72 \mathrm{~h}$ \\
\hline TPCan & NA 2 & pouring & anaerobic & $25^{\circ} \mathrm{C}$ & $48-72 \mathrm{~h}$ \\
\hline Sporulating bacteria & AA & pouring & aerobic & $37^{\circ} \mathrm{C}$ & $48-72 \mathrm{~h}$ \\
\hline Microscopic fungi & $\mathrm{CD}, \mathrm{MA}$ & pouring & aerobic & $25^{\circ} \mathrm{C}$ & 5-7 days \\
\hline
\end{tabular}




\section{RESULTS AND DISCUSSION}

\section{Physico-chemical quality of honeys}

The results from the physico-chemical analyses of acacia, other unifloral and multifloral honeys are recorded in the Table 3, 4 and 5 .

The water content is a quality parameter, important above all for honey shelf life (Bogdanov et al., 2004). Honey contains $15-21 \%$ of water (Kukurová et al.,

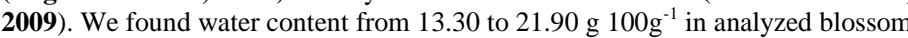
samples. Three samples exceeded the limit value of Codex Stan (2001) that is 20

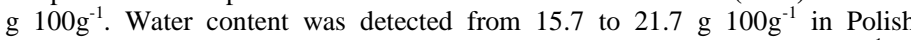

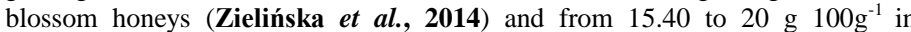
Romanian blossom honey (Mărghitas et al., 2009). According to Chaven (2014), honey with 1000 yeast spores or less per gram will remain stable at water content between $17.1 \%$ and $18.0 \%$, while if the water content is between $18.1 \%$ and $19.0 \%$, it would be expected that yeast would be able to grow and ferment the honey.

Water activity of tested honeys ranged from 0.485 (in acacia honey) to 0.629 (in multifloral honey). Most honeys possess a water activity of approximately 0.600 and many microbial species require water activity values between 0.940 and 0.990 in order to grow (Cooper, 2005). Yeasts require lower minimal water activity, between 0.910 and 0.880 and osmotolerant species Zygosaccharomyces rouxii and $Z$. bailii are capable of reproducing when the water activity is as low as 0.73 (Šilhánková, 2002).

$\mathrm{HMF}$ values in analyzed samples ranged from 0.77 to $10.93 \mathrm{mg} \mathrm{kg}^{-1}$. All samples were in accordance with Codex Stan (2001), where the limit value is $40 \mathrm{mg} \mathrm{kg}^{-1}$. Zielińska et al. (2014) found HMF in concentration from 0.5 to $28.0 \mathrm{mg} \mathrm{kg}^{-1}$ in the Polish unifloral and multifloral honeys. Amir et al. (2010) found very low HMF content in fresh Algerian honeys, HMF values ranged from 0.003 to 1.29 $\mathrm{mg} \mathrm{kg} \mathrm{kg}^{-1}$. HMF level serves as a quality measure for excessive heat during extraction, storage changes as HMF increases over time, or for possible adulteration with sugars and syrup (Chaven, 2014). Heat-treatment of honey causes the degradation of vitamins, nutritional components and decreases the diastase activity and increases the HMF content (Kukurová $\boldsymbol{e t}$ al., 2009).

The average value of free acidity was $12.31 \pm 2.69 \mathrm{meq} \mathrm{kg}^{-1}$ in acacia honey, $20.50 \pm 9.30 \mathrm{meq} \mathrm{kg}{ }^{-1}$ in other unifloral honeys and $24.27 \pm 13.24 \mathrm{meq} \mathrm{kg}^{-1}$ in multifloral honeys. One sample exceeded the limit value of Codex Stan (2001) that is max 50 meq $\mathrm{kg}^{-1}$. Zielińska et al. (2014) found similar free acidity in unifloral and multifloral Polish honeys (from 9.0 to $50.8 \mathrm{meq} \mathrm{kg}^{-1}$ ) and they found the highest acidity in the buckwheat honey, while the rape honey was characterized by the lowest content of this parameter. The $\mathrm{pH}$ values in the analyzed samples ranged from 4.60 to 5.50 in acacia and other unifloral honeys and from 3.80 to 5.20 in multifloral honeys. According to Bogdanov et al. (2004) all honeys are acidic with $\mathrm{pH}$-value of unifloral honeys generally lying between 3.5 and 5.5, due to the presence of organic acids that contribute to honey flavour and stability against microbial spoilage. Kisala and Dżugan (2009) stated that one of the physico-chemical factors influenced the antimicrobial activity is acidity of honey (with the average $\mathrm{pH}$ value 4.1 ), which is caused by the organic acids presence; acidity together with high osmotic pressure hinder the development of bacteria and osmophile yeasts.

Honey contains small amounts of different enzymes, the most important ones being diastase ( $\alpha$ - and $\beta$-amylase), invertase ( $\alpha$-glucosidase), glucose oxidase, catalase and acid phosphatase, which come from nectar sources, salivary fluids and from the pharyngeal gland secretions of the honeybee (Serrano et al., 2007) We detected the diastase number, which ranged from 10.45 DN (in acacia honey) to $52.36 \mathrm{DN}$ (in multifloral honey). The lowest diastase average value was found in acacia honeys $(18.60 \pm 7.19 \mathrm{DN})$. Similar results for acacia honey from Spain published Juan-Borrás et al. (2014). The highest average value was found in multifloral honeys $(25.81 \pm 10.38 \mathrm{DN})$. All samples were in accordance with Codex Stan (2001). According to Kukurová et al. (2009), enzyme activity decreases at $25^{\circ} \mathrm{C}$ after $8-10$ months of storage.

Table 3 Physico-chemical quality of acacia honeys

\begin{tabular}{|c|c|c|c|c|c|c|}
\hline & $\begin{array}{c}\text { Water content } \\
{\left[{\left.\mathrm{g} 100 \mathrm{~g}^{-1}\right]}\right.}\end{array}$ & Water activity & $\begin{array}{c}\mathrm{HMF} \\
{\left[\mathrm{mg} \mathrm{kg}^{-1}\right]}\end{array}$ & $\mathrm{pH}$ & $\begin{array}{c}\text { Free acidity } \\
{\left[\mathrm{meq} \mathrm{kg}^{-1}\right]}\end{array}$ & Diastase $[\mathrm{DN}]$ \\
\hline $\mathrm{n}$ & 14 & 14 & 11 & 14 & 14 & 14 \\
\hline average & 15.78 & 0.529 & 3.18 & 5.02 & 12.31 & 18.60 \\
\hline $\mathrm{SD}$ & 1.47 & 0.030 & 1.37 & 0.25 & 2.69 & 7.19 \\
\hline $\min$ & 13.60 & 0.485 & 0.97 & 4.60 & 8.90 & 10.71 \\
\hline $\max$ & 19.00 & 0.586 & 5.59 & 5.50 & 18.00 & 35.38 \\
\hline coef. var. [\%] & 9.30 & 5.72 & 43.10 & 4.95 & 21.88 & 38.67 \\
\hline
\end{tabular}

Legend: HMF - hydroxymethylfurfural, $\mathrm{n}$ - number of samples with measured values, SD - standard deviation, min -minimum, max - maximum, coef. var. - coefficient of variation

Table 4 Physico-chemical quality of other unifloral honeys

\begin{tabular}{|c|c|c|c|c|c|c|}
\hline & 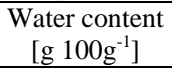 & Water activity & $\begin{array}{c}\mathrm{HMF} \\
{\left[\mathrm{mg} \mathrm{kg}^{-1}\right]}\end{array}$ & $\mathrm{pH}$ & $\begin{array}{c}\text { Free acidity } \\
{\left[\mathrm{meq} \mathrm{kg}^{-1}\right]}\end{array}$ & Diastase $[\mathrm{DN}]$ \\
\hline $\mathrm{n}$ & 8 & 8 & 7 & 8 & 8 & 8 \\
\hline average & 16.74 & 0.548 & 5.00 & 4.98 & 20.50 & 23.85 \\
\hline $\mathrm{SD}$ & 1.37 & 0.030 & 2.94 & 0.31 & 9.30 & 7.58 \\
\hline $\min$ & 14.80 & 0.507 & 2.20 & 4.60 & 12.50 & 10.45 \\
\hline $\max$ & 18.30 & 0.585 & 10.93 & 5.50 & 41.50 & 31.63 \\
\hline coef. var. [\%] & 8.18 & 5.53 & 58.82 & 6.24 & 45.35 & 31.78 \\
\hline
\end{tabular}

Legend: HMF - hydroxymethylfurfural, $\mathrm{n}$ - number of samples with measured values, SD - standard deviation, min -minimum, max - maximum, coef. var. - coefficient of variation

Table 5 Physico-chemical quality of multifloral honeys

\begin{tabular}{|c|c|c|c|c|c|c|}
\hline & $\begin{array}{c}\text { Water content } \\
{\left[\mathrm{g} 100 \mathrm{~g}^{-1}\right]}\end{array}$ & Water activity & $\begin{array}{c}\mathrm{HMF} \\
{\left[\mathrm{mg} \mathrm{kg}^{-1}\right]}\end{array}$ & $\mathrm{pH}$ & $\begin{array}{c}\text { Free acidity } \\
{\left[\mathrm{meq} \mathrm{kg}^{-1}\right]}\end{array}$ & Diastase [DN] \\
\hline $\mathrm{n}$ & 16 & 16 & 15 & 16 & 16 & 16 \\
\hline average & 17.41 & 0.558 & 4.01 & 4.66 & 24.27 & 25.81 \\
\hline SD & 2.25 & 0.036 & 1.71 & 0.45 & 13.24 & 10.38 \\
\hline $\min$ & 14.40 & 0.504 & 0.77 & 3.80 & 10.40 & 14.85 \\
\hline $\max$ & 21.90 & 0.629 & 7.05 & 5.20 & 50.20 & 52.36 \\
\hline coef. var. $[\%]$ & 12.92 & 6.50 & 42.64 & 9.62 & 54.56 & 40.22 \\
\hline
\end{tabular}

Legend: HMF - hydroxymethylfurfural, $\mathrm{n}$ - number of samples with measured values, $\mathrm{SD}$ - standard deviation, min - minimum, max - maximum, coef. var. coefficient of variation 


\section{Microbiological quality of honeys}

The results from microbiological analyses of acacia, other unifloral and multifloral honeys are recorded in the Table 6, 7 and 8 .

Coliform bacteria were not detected in all blossom honey samples. Generally, the presence of coliform bacteria is not allowed in food products and indicates faecal contamination. However, sometimes coliform bacteria can be found in fresh honey samples, as in study of Omafuvbe and Akanbi (2009), who found these bacteria only in one sample at low count $\left(1.48 \log \mathrm{CFU} \mathrm{g} \mathrm{g}^{-1}\right)$. The predominant microorganisms found in honey are derived from the nectar and the honey bee (Chaven, 2014).

TPC was detected in all samples instead of one acacia honey. TPC ranged from 1.00 to $3.48 \log \mathrm{CFU} \mathrm{g}{ }^{-1}$. The higher TPC value (above $2.00 \log \mathrm{CFU} \mathrm{g} \mathrm{g}^{-1}$ ) was exceeded in two acacia honeys, one sample of clover and rape honey and five samples of multifloral honeys. Różańska (2011) found similar TPC values in unifloral and multifloral Polish honeys; they ranged from 1.00 to $4.88 \log \mathrm{CFU} g$ ${ }^{1}$. Omafuvbe and Akanbi (2009) found TPC between 3.00 and $3.70 \log \mathrm{CFU} \mathrm{g}^{-1}$. According to Snowdon and Cliver (1996) bacterial numbers of finished honeys tends to range from 1 to $5000 \mathrm{CFU} \mathrm{g}^{-1}\left(0-3.70 \log \mathrm{CFU} \mathrm{g} \mathrm{g}^{-1}\right)$, with lower numbers possible with additional industrial treatment.
Total plate count of anaerobic bacteria was detected only in 2 samples of acacia honey (14.29\%), in 1 chestnut honey (12.50\% of other unifloral honeys) and in 8 samples of multifloral honeys (50.00\%). These values ranged from 1.00 log CFU $\mathrm{g}^{-1}$ (in chestnut honey) to $2.89 \log \mathrm{CFU} \mathrm{g}^{-1}$ (in multifloral honey). Isolates were not identified at genus level. Some lactic acid bacteria (LAB) belong to the anaerobic bacteria and Olofsson and Vásquez (2008) discovered some LAB of the genera Lactobacillus and Bifidobacterium in the honey stomach of the honeybee and these organisms can end up eventually in the honey; they suggested that honey shall be considered as a fermented food product because of the LAB involved in honey production. According to Snowdon and Cliver (1996), Pseudomonas sp. and Micrococcus sp. might also be found in the honey samples. These bacteria are aerobic generally and non-sporulating, but tolerant to external unfavourable factors. Longaric et al. (2011) identified isolates from the honey samples as Comamonas sp. and Acinetobacter sp. that are aerobic bacteria too. The most osmotolerant bacteria (i. e. those which can survive in high sugar concentration) are staphylococci (Cooper, 2005).

Table 6 Microbiological quality of acacia honeys $\left[\log \mathrm{CFU} \mathrm{g} \mathrm{g}^{-1}\right]$

\begin{tabular}{lccccc}
\hline & TPC & TPCan & SB & Yeasts & MFF \\
\hline $\mathrm{n}$ & 13 & 2 & 6 & 6 & 7 \\
average & 1.51 & 1.41 & 1.67 & 1.22 & 1.24 \\
$\mathrm{SD}$ & 0.47 & 0.21 & 0.76 & 1.00 & 0.40 \\
$\min$ & 1.00 & 1.26 & 1.26 & 1.95 & 1.00 \\
$\max$ & 2.42 & 1.56 & 3.19 & 31.71 & 2.07 \\
coef. var. [\%] & 30.83 & 15.04 & 45.32 & 32.22 \\
\hline
\end{tabular}

Legend: CFU - colony forming unit, TPC - total plate count, TPCan - total plate count of anaerobic microorganisms, SB - sporulating bacteria, MFF microscopic filamentous fungi, $\mathrm{n}$ - number of samples with measured values, $\mathrm{SD}$ - standard deviation, min - minimum, max - maximum, coef. var. - coefficient of variation

Table 7 Microbiological quality of other unifloral honeys [log $\left.\mathrm{CFU} \mathrm{g}{ }^{-1}\right]$

\begin{tabular}{|c|c|c|c|c|c|}
\hline & TPC & TPCan & SB & Yeasts & MFF \\
\hline $\mathrm{n}$ & 8 & 1 & 1 & 4 & 4 \\
\hline average & 1.75 & 1.00 & 1.00 & 1.48 & 1.58 \\
\hline $\mathrm{SD}$ & 0.57 & ND & ND & 0.71 & 1.04 \\
\hline $\min$ & 1.00 & 1.00 & 1.00 & 1.00 & 1.00 \\
\hline $\max$ & 2.85 & 1.00 & 1.00 & 2.50 & 3.13 \\
\hline coef. var. [\%] & 32.58 & ND & $\mathrm{ND}$ & 48.06 & 65.83 \\
\hline
\end{tabular}

Legend: CFU - colony forming unit, TPC - total plate count, TPCan - total plate count of anaerobic microorganisms, SB - sporulating bacteria, MFF of variation

Table 8 Microbiological quality of multifloral honeys $\left[\log \mathrm{CFU} \mathrm{g} \mathrm{g}^{-1}\right]$

\begin{tabular}{|c|c|c|c|c|c|}
\hline & TPC & TPCan & SB & Yeasts & MFF \\
\hline $\mathrm{n}$ & 16 & 8 & 10 & 8 & 11 \\
\hline average & 1.96 & 1.90 & 1.66 & 1.54 & 1.34 \\
\hline $\mathrm{SD}$ & 0.70 & 0.84 & 0.72 & 0.61 & 0.51 \\
\hline $\min$ & 1.08 & 1.00 & 1.00 & 1.00 & 1.00 \\
\hline $\max$ & 3.48 & 2.89 & 2.82 & 2.73 & 2.79 \\
\hline coef. var. [\%] & 35.61 & 44.28 & 43.07 & 39.31 & 38.23 \\
\hline
\end{tabular}

Legend: CFU - colony forming unit, TPC - total plate count, TPCan - total plate count of anaerobic microorganisms, SB - sporulating bacteria, MFF microscopic filamentous fungi, $\mathrm{n}$ - number of samples with measured values, $\mathrm{SD}$ - standard deviation, min - minimum, max - maximum, coef. var. - coefficient of variation

Sporulating bacteria count was detected in 6 acacia honeys $(42.86 \%)$, in 1 rape honey (12.50\% of other unifloral honeys) and in 10 multifloral honeys $(62.50 \%)$ Counts of sporulating bacteria ranged from $1.00 \mathrm{log} \mathrm{CFU} \mathrm{g}^{-1}$ (in rape honey) to $3.19 \log \mathrm{CFU} \mathrm{g} \mathrm{g}^{-1}$ (in acacia honey). Omafuvbe and Akanbi (2009) found sporulating bacteria ranged from 2.90 to $3.30 \mathrm{log}$ CFU g ${ }^{-1}$. Tolba et al. (2007) isolated the sporulating bacteria from honey samples with counts ranged from

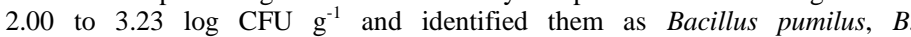
licheniformis, B. subtilis, B. fusiformis and Paenibacillus motobuensis, with Bacillus pumilus the most frequently identified species present. Bacterial spores, particularly those in the Bacillus genus, are regularly found in honey (Snowdon and Cliver, 1996).

Yeasts were detected in 6 acacia honeys $(42.86 \%)$, in 4 other unifloral honeys $(50.00 \%)$ and in 8 multifloral honeys $(50.00 \%)$. Yeasts ranged from 1.00 to 2.73 $\log \mathrm{CFU} \mathrm{g}^{-1}$. Higher yeasts count (above $2.00 \log \mathrm{CFU} \mathrm{g}^{-1}$ ) was found in 1 sample of lime honey and 2 samples of multifloral honey. Nectar itself has a microbial community associated with bees and yeasts are the most frequent inhabitants of floral nectar (Escuredo et al., 2012). Osmophile and sugar tolerant yeasts are a problem in the honey industry, because they can grow even at the limited level of water available in ripe honey (Snowdon and Cliver, 1996) and under the right environment, may grow and ferment honey resulting in the formation of alcohol and carbon dioxide and a sour taste from breakdown of alcohol to acetic acid and water (Chaven, 2014).

Microscopic filamentous fungi were found in 7 acacia honeys $(50.00 \%)$, in 4 other unifloral honeys (50.00\%) and in 11 multifloral honeys $(68.75 \%)$. MFF counts ranged from $1.00 \log \mathrm{CFU} \mathrm{g} \mathrm{g}^{-1}$ to $3.13 \log _{\mathrm{CFU} \mathrm{g}}{ }^{-1}$ (in buckwheat honey). Higher MFF counts (above $2.00 \mathrm{log} \mathrm{CFU} \mathrm{g}^{-1}$ ) was detected in 1 sample of acacia honey, 1 sample of buckwheat honey and 1 sample of multifloral honey. Presence of microscopic fungi was not detected in 3 acacia honeys $(21.43 \%), 1$ clover and 1 rape honey (25.00\% of other unifloral honeys) and in 2 multifloral honeys (12.50\%). Różańska (2011) found relatively low number of yeasts and MFF in Polish blossom honeys, too; their number exceeded $2.00 \log \mathrm{CFU} \mathrm{g}$ sporadically. The similar results were published by Martins et al. (2003), who detected microscopic fungi in $88.8 \%$ of honey samples and identified three genera of microscopic filamentous fungi (Aspergillus, Penicillium and Mucor) and two genera of yeasts (Saccharomyces and Candida).

\section{CONCLUSION}

We tested three groups of blossom honey (acacia, other unifloral and multifloral), mainly originated in Slovakia. Three samples of multifloral honey exceed at least one of the physico-chemical parameters limit value. HMF and diastase values of all evaluated samples were in accordance with limit value. It indicates the correct way of honey processing and storage. Overall, the good quality of tested honey samples was found. Ripe honey of good quality has the unique physico-chemica properties that are unfriendly to vegetative bacterial cells. Probably, they are destroyed gradually during the maturation and storage and we can isolate some of the most tolerant in relatively fresh honeys. Multifloral honey comes from nectar of various plants. Consequently, honey contains wide range of chemical 
substances, and various microorganisms come to the honey. That is probably the reason why all evaluated microbial groups were found in higher frequency in the multifloral honey compared to the acacia and other unifloral honey.

Acknowledgments: This study was supported by the project VEGA 1/0129/13

\section{REFERENCES}

AMIR, Y., YESLI, A., BENGANA, M., SADOUDI, R., AMROUCHE, T. 2010 Physico-chemical and microbiological assessment of honey from Algeria. Electronic Journal of Environmental, Agricultural and Food Chemistry, 9(9), 1485-1494.

BOGDANOV, S., RUOFF, K., PERSANO ODDO, L. 2004. Physico-chemical methods for the characterisation of unifloral honeys: a review. Apidologie, 35(1), S4-S17. http://dx.doi.org/10.1051/apido:2004047

BOGDANOV, S., JURENDIC, T., SIEBER, R., GALLMANN, P. 2008. Honey for Nutrition and Health: A Review. Journal of the American College of Nutrition, 27(6), 677-689. http://dx.doi.org/10.1080/07315724.2008.10719745

CHAVEN, S.2014. Chapter 11 - Honey, Confectionery and Bakery Products Food Safety Management, 283-299. ISBN 978-0-12-381504-0. http://dx.doi.org/10.1016/B978-0-12-381504-0.00011-1

Codex Stan. 2001. Codex Standard for Honey 12-1981. Adopted in 1981. Revisions 1987 and 2001

COOPER, R. 2005. Chapter 2 - The antimicrobial activity of honey. Honey: A Modern Wound Management Product, 24-26.

ESCUREDO, O., FERNÁNDEZ-GONZÁlEZ, M., SEIJO, M. C. 2012. Differentiation of Blossom Honey and Honeydew Honey from Northwest Spain. Agriculture, 2(1), 25-37. http://dx.doi.org/10.3390/agriculture2010025

IHC. 2009. Harmonised methods of the International Honey Commission. 63 p. JUAN-BORRÁS, M., DOMENECH, E., HELLEBRANDOVA, M., ESCRICHE I. 2014. Effect of country origin on physicochemical, sugar and volatile composition of acacia, sunflower and tilia honeys. Food Research International, 60, 86-94. http://dx.doi.org/10.1016/j.foodres.2013.11.045

KAMLER, F., TITĚRA, D., VESELÝ, V. 1999. Získávání a zpracování včelích produktů. Praha : Institut výchovy a vzdělávání MZ Č, 48 p. ISBN 80-7105196-9.

KISAŁA, J., DŻUGAN, M. 2009. Wpływ stanu środowiska i sposobu utrzymania pszcół na jakość miodu. Zeszyty Naukowe : Zeszyt 11, 115-120.

KUKUROVÁ, K., KOHAJdOVÁ, Z., KAROVIČOVÁ, J., VRBIKOVÁ, L. 2009. Authentication parameters suitable for detection of honey adulteration. Potravinárstvo, 3(2), 44-50.

LONGARIC, I., RUPPITSCH, W., LICEK, E., MOOSBECKHOFER, R. BUSSE, H. J., ROSENGARTEN, R. 2011. Characterization of selected Gramnegative non-fermenting bacteria isolated from honey bees (Apis mellifera carnica). Apidologie, 42(3), 312-325. http://dx.doi.org/10.1007/s13592-0110019-7

MARTINS, H. M., MARTINS, M. L., BERNARDO, F. M. A. 2003. Bacillaceae spores, fungi and aflatoxins determination in honey. Revista Portuguesa de Ciências Veterinárias, 98(546), 85-88.

MĂRGHITAS, L. A., DEZMIREAN, D., MOISE, A., BOBIS, O., LASLO, L., BOGDANOV, S. 2009. Physico-chemical and bioactive properties of different floral origin honeys from Romania. Food Chemistry, 112(4), 863-867. http://dx.doi.org/10.1016/j.foodchem.2008.06.055

OLOFSSON, T. C., VÁSQUEZ, A. 2008. Detection and Identification of a Novel Lactic Acid Bacterial Flora Within the Honey Stomach of the Honeybee Apis mellifera. Current Microbiology, 57(4), 356-363. http://dx.doi.org/10.1007/s00284-008-9202-0

OMAFUVBE, B. O., AKANBI, O. O. 2009. Microbiological and physicochemical properties of some commercial Nigerian honey. African Journal of Microbiology Research, 3(12), 891-896.

RÓŻAŃSKA, H. 2011. Microbiological quality of polish honey. Bull Vet Inst Pulawy, 55, 443-445.

SERRANO, S., ESPEJO, R., VILLAREJO, M., JODRAL, M. L. 2007. Diastase and invertase activities in Andalusian honeys. International Journal of Food Science and Technology, 31(1-3), 1-26. http://dx.doi.org/10.1111/j.13652621.2006.01213.x

SINACORI, M., FRANCESCA, N., ALFONZO, A., CRUCIATA, M., SANNINO, C., SETTANNI, L., MOSCHETTI, G. 2014. Cultivable microorganisms associated with honeys of different geographical and botanical $\begin{array}{llll}\text { origin. } & \text { Food } & \text { Microbiology, } & 38,\end{array}$ http://dx.doi.org/10.1016/j.fm.2013.07.013

SNOWDON, J. A., CLIVER, D. O. 1996. Microorganisms in honey. International Journal of Food Microbiology, 31(1-3), 1-26. http://dx.doi.org/10.1016/0168-1605(96)00970-1

ŠILHÁNKOVÁ, L. 2002. Mikrobiologie pro potravináře a biotechnology. Praha : Academia, 363 p. ISBN 80-200-1024-6.

TITĚRA, D. 2006. Včelí produkty mýtů zbavené: med, vosk, pyl, matěří kašička, propolis, včelí jed. Praha : Brázda, 176 p. ISBN 80-209-0347-X.

TOLBA, O., EARLE, J. A. P., MILLAR, B. CH., ROONEY, P. J., MOORE, J

E. 2007. Speciation of Bacillus spp. in honey produced in Northern Ireland by employment of $16 \mathrm{~S}$ rDNA PCR and automated DNA sequencing techniques. World Journal of Microbiology and -biotechnology, 23(12), 1805-1808. http://dx.doi.org/10.1007/s11274-007-9425-4

VESELÝ, V., BACÍLEK, J., KAMLER F. et al. 2003. Včelařství. Praha : Brázda 257 p. ISBN 80-209-0320-8.

VORLOVÁ, L., ČELECHOVSKÁ, O. 2002 Activity of Enzymes and Trace Element Content in Bee Honey. Acta Vet. Brno, 71, 375-378. http://dx.doi.org/10.2754/avb200271030375

ZIELIŃSKA， S., WESEŁOWSKA， M., BILEK, M., KANIUCZAK, J., DŻUGAN, M. 2014. The saccharide profile of polish honeys depending on their botanical origin. J Microbiol Biotech Food Sci, 3(5), 387-390. 